\title{
気象観測データと熱収支モデルに基づく地上積雪重量推定法 \\ 長岡市の観測データを対象としたモデルの感度解析と精度検証 \\ METHOD TO ESTIMATE GROUND SNOW WEIGHT BASED ON METEOROLOGICAL OBSERVATION DATA AND HEAT BALANCE MODEL
}

Sensitivity analysis and validation of a model based on measurement data for Nagaoka

富 永 禎 秀*1, 本吉弘 岐*2

Yoshihide TOMINAGA and Hiroki MOTOYOSHI

\begin{abstract}
A versatile method to estimate the weight of ground snow based on meteorological observation data and a heat balance model was proposed. The performance of the model in terms of estimating the maximum and 7-day increasing snow weights was validated through a comparison with measurement data of Nagaoka for eight winters. The sensitivity of the model parameters and accuracy were examined considering daily variation in snow weight. Furthermore, a disadvantage of the model, in that it requires a number of meteorological factors, could be overcome by estimating the unmeasured meteorological factors using the concept of extended AMeDAS meteorological data.
\end{abstract}

Keywords: Ground snow weight, Estimation method, Heat balance model, Meteorological observation data 地上積雪重量, 推定法, 熱収支モデル, 気象観測データ

\section{1. はじめに}

屋根雪荷重を正確に推定することは、積雪地域の安全な建築構造 性能を確保する上で重要である。建築基準法において、屋根雪荷重 を算定するための地上積雪重量は、各特定行政庁で指定されている 垂直積雪量に単位重量を乗じて算定することとされている。ここで 単位重量は、多雪区域が $30 \mathrm{~N} / \mathrm{m}^{2} / \mathrm{cm}$ 以上、それ以外の地域が $20 \mathrm{~N} / \mathrm{m}^{2} / \mathrm{cm}$ 以上と規定されている。しかし、2014 年 2 月の関東地 方での大雪のように、降雪後に降雨があるようなケースでは、この ような単位重量では積雪重量は過小に評価されてしまう1)。積雪の 密度が、気象条件や降雪後の経過時間、積雪の内部構造等によって 大きく異なることはよく知られており、このような一律の単位重量 を用いることは、積雪の本来の性質からは乘離している。設計者に 対して誤解を生じさせないよう直接的に荷重值を示すことが本来は 望ましく、海外の基準 (例えば ASCE $7^{3}$ ) ) 等では、面積当たりの地 上積雪重量が直接的に規定されている 2)。また 2004 年以降の日本 建築学会の建築物荷重指針・同解説 4)では、降水量と気温に基づい て算出された地上積雪重量の再現期待值 100 年の值が提示されてい る。

文献 4 で示されている降水量と気温に基づいて計算された地上積 雪重量は、Takahashi ら 5の方法を用いている。この方法は、最小 密度 $\rho_{\min }$ と融雪係数 $C_{m}$ をパラメータとし、降水量から降雪イベント
ごとに形成される積雪層の時刻歴を推定することによって地上積雪 重量の最大值を求めるものである。これらのパラメータの最適值を 決定するためには、観測された積雪深の時刻歴に対して最も誤差が 小さくなるパラメータを事前にチューニングする必要があるため一 冬期のデータが揃ってからの解析が前提である。メリットとしては、 モデルの入力值として必要な気象要素は降水量と日平均気温、積雪 深だけであり、適用できる地点が多いことである。なお建築分野に おける地上積雪重量の推定方法に関する研究としては、他に桜井・ 城 6,7)のものがあるが、融雪量は後述の Degree-Day 法を用いるか、 最大值の推定には寄与が小さいとして考慮されていない。

日平均気温と融雪限界気温の差の積算值に融雪係数をかけて融雪 量を求める方法は、Degree-Day 法と呼ばれ、古くから様々な分野 で使用されている 8,9)。Takahashi らのモデルやDegree-Day 法は、 実際の融雪量を決定する日射、顕熱・潜熱の熱交換などによって構 成される雪面の熱収支を、日平均気温という一つのパラメータに代 表させ、その感度を融雪係数で調整していると解釈できる。少ない 入力データで簡便に利用できる点は大きなメリットであり、現状の 雪荷重推定において重要な役割を担っている 4,5)。しかしながら融 雪係数は経験的な值であり、物理的な意味は必ずしも明確ではない ことから、将来的な気候変化一の対応など多様な気候条件一の適用 性の課題も指摘できる。一方、地上積雪重量の推定を直接の目的と
新潟工科大学工学科 教授・博士 (工学) 国立研究開発法人防災科学技術研究所雪水防災研究部門 主任研究員・博士 (理学)
Prof., Faculty of Engineering, Niigata Institute of Technology, Ph.D. Researcher, Snow and Ice Research Division, National Research Institute for Earth Science and Disaster Resilience, Ph.D. 
はしていないものの、積雪内部の熱収支や水分移動を考慮して積雪 の層構造を計算するモデルとして、平島ら ${ }^{11)}$ や藤本ら ${ }^{12)}$ の研究があ るが、これらのモデルは、複雑な方程式系が採用されているためモ デルに含まれる数值パラメータが膨大で、これらのチューニングに 課題があるほか、計算アルゴリズムも複雑である。

以上のことから、地上積雪重量変化を支配する熱収支要因を考慮 しつつ、経験的な係数のチューニングを極力回避した汎用的かつ簡 便な地上積雪重量の推定モデルの開発は意義あることと考えられる。 また熱収支に基づく方法は、積雪重量を決定する気象的メカニズム が直接組み込まれているので、地上積雪に比べて日射や風速などの 気象要素の影響を受けやすいと考えられる屋根上積雪（雪荷重） の応用も容易であることが期待される。

本研究では、気象データと熱収支モデルに基づき、汎用性および 適用性の高い地上積雪重量推定モデルを開発することを目的とする。 本報では、推定法の概要を説明するとともに、その手法を用いて、 代表的な積雪都市の一つである新潟県長岡市の詳細な気象観測デー 夕に基づいて地上積雪重量の推定を行う。そして同条件下で計測さ れた積雪重量の観測值との比較により、使用するパラメータの感度 解析を行うとともに、その精度を検証する。さらに本手法のような 多くの気象要素を用いるモデルの欠点である、必要な気象要素の観 測が行われている地点が限られてしまうという課題に対して、気象 庁の地域気象観測所（アメダス）の気象データのみでも適用できる 方法を検討する。

\section{2. 解析概要}

\section{1 積雪重量の算出方法}

降水量の積算値から、融雪による流出量を引いたものが積雪重量 になる。この考え方は、Takahashi らの方法 5) と同様である。本研 究では 1 時間ごとの気象要素を用いて逐次的に計算を行う注1)。なお 本手法では積雪重量のみを計算対象としており、積雪深は計算過程 には現れない。

\section{(1) 雨雪の判定}

降水量は、雨雪判別気温 $T_{S R}$ 以上で降雨によるもの、 $T_{S R}$ 未満で降雪 によるものとみなす。本手法では、後述する積雪内の水分量の計算 と降水量計の捕捉率係数の選択、そしてアルベドの計算時に $T_{S R}$ を使 用する。既往の研究では判別気温として $2^{\circ} \mathrm{C}$ を用いている場合が多 いが 4, 6)、山口ら 13)は、長岡と新庄で観測された積雪深と積雪密度 から求めた総雪降水量と実際の降雪水量の一致する判別気温として $0.5^{\circ} \mathrm{C}$ を得ている。このように既往研究の $T_{S R}$ の選択には幅があるこ とから、3.2 において推定結果一の感度解析を行う。

（2）降水量の補正

降雪による降水量は風速の影響を受け、実際よりも過小に計測さ れる傾向が知られており 5)、横山らにより風速と機器別の係数を用 いた捕捉率の計算式が提案されている ${ }^{14)}$ 。計測された降水量はこの 捕捉率を用いて、時刻別のデータに対して次式で補正を行った。

$$
\begin{aligned}
& P^{\prime}=P / C_{R} \\
& P: \text { 降水量計による計測值 } \\
& C_{R}: \text { 捕捉率 }
\end{aligned}
$$

捕捉率は雨と雪の場合でそれぞれ示されているので、本研究では、 その適用に際して前述の判別気温 $T_{S R}$ 用いた。

\section{(3) 流出量の算出}

融雪量（流出量）の算出には、近藤・山崎 ${ }^{14)}$ のモデルを用いた。 このモデルでは積雪は 1 つの層（単層）として扱われており、積雪 の内部構造は検討対象としていない。融雪によって水から水に変化 する 1 時間当たり単位面積あたりの重量 $M W$ は、融雪エネルギー $M$ （後述）を用いて次式で表される。

$$
\begin{aligned}
M W & =3600 M / C_{M} \\
C_{M} & : \text { 水の融解熱 }\left(0^{\circ} \mathrm{C} \text { で } 0.344 \times 10^{6}[\mathrm{~J} / \mathrm{kg}]\right)
\end{aligned}
$$

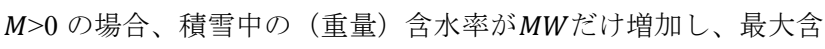
水量 $L W_{M A X}\left(C L W_{M A X} \times S W\right.$; ここで $S W$ は積雪重量、C $C L W_{M A X}$ は最大含 水率）を超えた分が新たな流出水量となる。近藤・山崎 ${ }^{15)}$ の論文で はCLW $W_{M A X}$ として $5 \%$ 用いられている。しかしながら本研究と同じ 観測地点の含水率の測定結果 ${ }^{16) を}$ 見ると、積雪下層の地表付近で $5 \%$ 程度であるものの積雪層の平均では 7 10\%程度であることか ら、CLW た。

（4）融雪エネルギーの算出

積雪面表層の熱収支の構成を Fig. 1 に示す。表層の熱収支を考え ているので地中からの伝導熱は現れない。積雪面表層の熱収支は(3) 式で表せる。なお降水に伴う熱量は小さいものとして無視してい る9)。

$$
M=R^{\downarrow}-L^{\uparrow}-H-l E
$$

各構成要素は以下のように計算される。

(1) 入力放射量 $R^{\downarrow}\left[\mathrm{W} / \mathrm{m}^{2}\right]$

$$
\begin{aligned}
R^{\downarrow} & =(1-a) S^{\downarrow}+\varepsilon L^{\downarrow} \\
a & : \text { アルベド } \\
S^{\downarrow} & : \text { 全天日射量 }\left[\mathrm{W} / \mathrm{m}^{2}\right] \\
L^{\downarrow} & : \text { 大気放射量 }\left[\mathrm{W} / \mathrm{m}^{2}\right] \\
\varepsilon & : \text { 積雪の射出率 }(\text { 本研究では } 1.0 \text { とした) }
\end{aligned}
$$

(2) 上向き長波放射量 $L^{\uparrow}\left[\mathrm{W} / \mathrm{m}^{2}\right]$

$$
\begin{aligned}
& L^{\uparrow}=\varepsilon \sigma T_{s}{ }^{4} \\
& \sigma: \text { ステファン・ボルツマン定数 }\left[\mathrm{W} / \mathrm{m}^{2} / \mathrm{K}^{4}\right] \\
& T_{s}: \text { 積雪表面温度 }[\mathrm{K}]
\end{aligned}
$$

(3) 顕熱輸送量 $H\left[\mathrm{~W} / \mathrm{m}^{2}\right]$

$$
\begin{aligned}
& H=C_{P} \rho C_{H} U\left(T_{S}-T\right) \\
& C_{P}: \text { 空気の比熱 }[\mathrm{J} / \mathrm{kg} / \mathrm{K}] \\
& \left.\rho: \text { 空気の密度 }\left[\mathrm{kg} / \mathrm{m}^{3}\right]^{\text {i土 } 2}\right) \\
& C_{H}: \text { 顕熱輸送のバルク輸送係数（本研究では } 0.002 \text { とした） 注 } 3 \text { ) } \\
& U: \text { 高度 } 1.0 \mathrm{~m} \text { での風速 }[\mathrm{m} / \mathrm{s}] \\
& T: \text { 気温 }[\mathrm{K}]
\end{aligned}
$$

(4) 潜熱輸送量 $l E\left[\mathrm{~W} / \mathrm{m}^{2}\right]$

$$
\begin{aligned}
& l E=l \rho C_{E} U\left[(1-r h) q_{s a t}(T)+\Delta \cdot\left(T_{s}-T\right)\right] \\
& l: \text { 水の昇華の潜熱または水の気化の潜熱 }[J / \mathrm{kg}] \\
& C_{E}: \text { 潜熱輸送のバルク輸送係数 }(\text { 本研究では } 0.002 \\
& r h: \text { 相対湿度 } \\
& \left.q_{s a t}(T): \text { 気温に対する飽和比湿 }[\mathrm{kg} / \mathrm{kg}] \text { 注 } 4\right) \\
& \left.\Delta: \text { 飽和比湿の温度に対する変化率注 }{ }^{5}\right)
\end{aligned}
$$$$
C_{E}: \text { 潜熱輸送のバルク輸送係数（本研究では } 0.002 \text { とした） 注 } 3 \text { ) }
$$

(5) 融雪エネルギーM $\left[\mathrm{W} / \mathrm{m}^{2}\right]$

(1)〜 (4)の各要素が求まれば、(3)式から融雪エネルギー $M$ を計算す ることができるが、その際、次式により積雪表面温度 $T_{s}[\mathrm{~K}]$ を求め る。

$$
T_{S}=\frac{R^{\downarrow}-\varepsilon \sigma T^{4}-l \rho C_{H} U(1-r h) q_{s a t}(T)}{4 \varepsilon \sigma T^{3}+\left(l \Delta+C_{P}\right) \rho C_{H} U}+T
$$




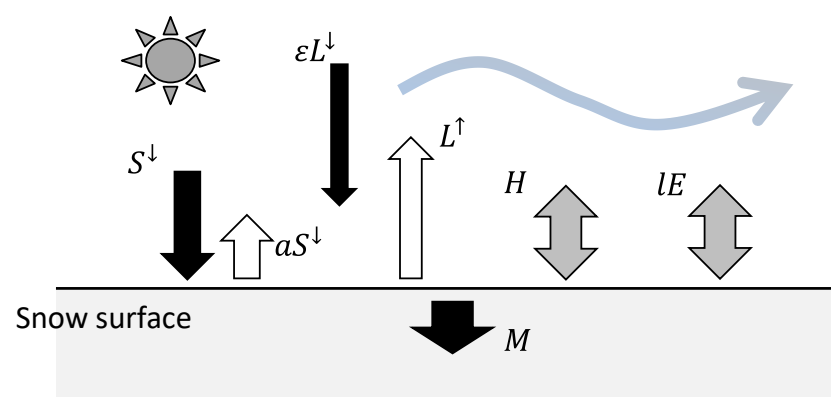

Fig. 1 Schematic of heat balance on snow surface

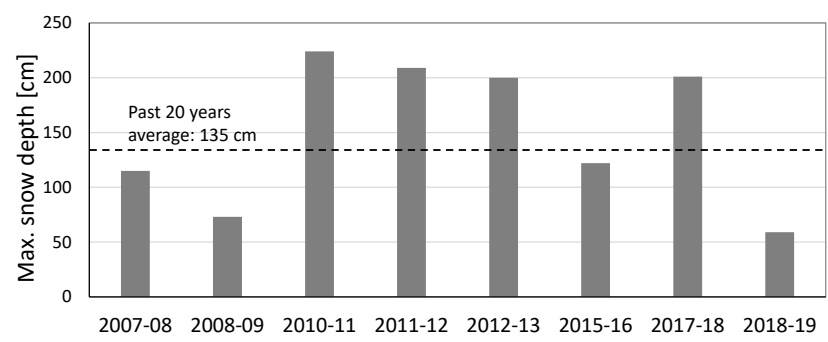

Fig. 2 Yearly maximum snow depths observed for eight winters

このように積雪表面温度の計算を線形化することで、収束解を求 めるための反復計算を行う必要がなく、簡便に熱収支計算を行うこ とが可能となる。(8)式で求めた $T_{s}$ が $0^{\circ} \mathrm{C}$ 以下であれば、融雪は起き ない $(M=0)$ として次のステップに進む。 $T_{s}>0^{\circ} \mathrm{C}$ とったときには、 $T_{s}=0^{\circ} \mathrm{C}$ とおいて、(3)式から $M$ を計算する。 $M>0$ なら $T_{s}=0^{\circ} \mathrm{C}$ といいた ことと整合するので、 $M$ を用いて融雪量を計算する。 $M<0$ の場合、 積雪内の液体水を再凍結させることになるが、 $T_{s}=0^{\circ} \mathrm{C}$ は一般に高す ぎることから、 $T_{S}=T$ として $M$ を計算しなおして凍結量を求める。

(5) アルベドモデル

(4)式中のアルベド $a$ は融雪過程に大きな影響を及ぼすことが知ら れている 11)。山崎ら 17)は、札幌において観測された気象データをも とにアルベドが時間の経過によって低下していく様子を次のような 指数関数で表現した。

$$
\begin{aligned}
& a_{n}=\left(a_{n-1}-a_{\text {min }}\right) \exp (-1 / k) \\
& a_{0}=a_{\text {max }} \\
& a_{\text {max }}=-0.12 T_{\text {mean }}+0.76\left(T_{\text {mean }} \geq-1.0^{\circ} \mathrm{C}\right) \\
& \quad=0.88\left(T_{\text {mean }} \leq-1.0^{\circ} \mathrm{C}\right)
\end{aligned}
$$

$a_{n}$ が降雪から $n$ 日後のアルベド、 $a_{\min }$ はアルベドの取り得る最小值 (0.40) である。 $a_{\max }$ は新雪のアルベドであり、日平均気温 $T_{\text {mean }}$ を 用いて推定される。 $k$ はアルベドの低下速さを表すパラメータで、 次式で表される。

$$
\begin{aligned}
k & =-4.9 T_{\text {mean }}+4.5\left(T_{\text {mean }} \leq 0.1^{\circ} \mathrm{C}\right) \\
& =4.0 \quad\left(T_{\text {mean }} \geq 0.1^{\circ} \mathrm{C}\right)
\end{aligned}
$$

山崎ら ${ }^{17)}$ は、このモデルについて、札幌以外で成り立つことは保 証しないと延べており、伊豫部ら ${ }^{18)}$ は、山崎らのモデルを温暖な本 州の新潟県に適用寸ると推定結果が過小評価になるとの理由で、ア ルベドの低下の速さを表す $k$ と $a_{\max }$ の係数を変更している。しかし ながら本研究では、極力、モデルパラメータなどのチューニングを 必要としないモデルを構築しようとする立場から、山崎ら 17)のモデ ルをそのまま使用した。
Table 1 Meteorological parameters required for the proposed method

\begin{tabular}{l|l|l}
\hline Meteorological factor & $\begin{array}{l}\text { Availability at } \\
\text { meteorological } \\
\text { office }\end{array}$ & $\begin{array}{l}\text { Availability } \\
\text { at AMeDAS } \\
\text { observation } \\
\text { point }\end{array}$ \\
\hline Precipitation & $\bigcirc$ & $\bigcirc$ \\
\hline Atmospheric pressure & $\bigcirc$ & - \\
\hline Air temperature & $\bigcirc$ & $\bigcirc$ \\
\hline Relative humidity & $\bigcirc$ & - \\
\hline Wind velocity & $\bigcirc$ & $\bigcirc$ \\
\hline Solar radiation & $\bigcirc$ & - \\
\hline Atmospheric radiation & $\bigcirc$ & - \\
\hline
\end{tabular}

\section{（6）入力条件として必要な気象要素}

本推定モデルで入力条件として必要な気象要素を Table 1 に示寸 気象官署では全ての気象要素が計測されており、入手可能であるが、 アメダス観測点では、観測されていない要素が含まれており、本モ デルの適用性における課題となる。この点は、 5 章で検討する。

\section{2 検証用観測データ}

新潟県長岡市の防災科学技術研究所・雪水防災研究センターの積 雪・気象観測露場で計測された各気象要素を入力条件として使用し た。また同露場でメタルウェハー式積雪重量計注 6)によって計測され た地上積雪重量を検証用のデータとした。降水量は RT-3（温水式） によるデータを用いたが、2017-18 冬期のみ久測があった都合で RT-4（溢水式）のデータを用いた。風速の測定高さは、 $8.7 \mathrm{~m}$ であ り、べき指数 0.15 のべき乗則で必要な高さに補正して使用した。そ の他の気象要素の観測方法の詳細は文献 19, 20 を参照されたい。

2008-09 冬期から 2018-19 冬期までの観測結果から、久測值の あった冬期を除いた 8 冬期の観測結果を使用した。対象とした 8 冬 期の最深積雪の比較を Fig. 2 に示寸。 8 冬期の最深積雪の平均值は $150 \mathrm{~cm}$ であり、過去 20 冬期の平均值 $(135 \mathrm{~cm})$ を上回っているこ とから、一定の降積雪のあった代表性のある観測值と考えられる。 なお以降の結果の表示に際しては、代表的な冬期として、8 冬期の 中で最深積雪が最大であった 1010-11 冬期と、地上積雪重量が最大 であった 2012-13 冬期を採り上げる。

\section{3. 観測結果との比較によるパラメータの決定と精度の検証 3. 1 アルベドモデルの精度の検証}

気象データとして、下向き短波放射量と上向き短波放射量が計測 されているので、その值からアルベドの真值を求めて、モデル（(9) 〜(12)式）による計算值と比較した。モデルのアルベドは日代表值 として算出されるが、観測結果は各日の正午の值とした。2010-11 と 2012-13 冬期の結果を Fig. 3 に示寸。特に積雪初期において、観測 のばらつきも大きいが、降雪及び経過日数に伴うアルベド変化の傾 向は十分捉えられていると判断される注 7)。

\section{2 雨雪判別気温と最大含水率の感度解析}

推定モデルの使用にあたって決定すべきパラメータである雨雪判 別気温 $T_{S R}$ と最大含水率 $C L W_{M A X}$ について、感度解析を行った。 
$2010-11$
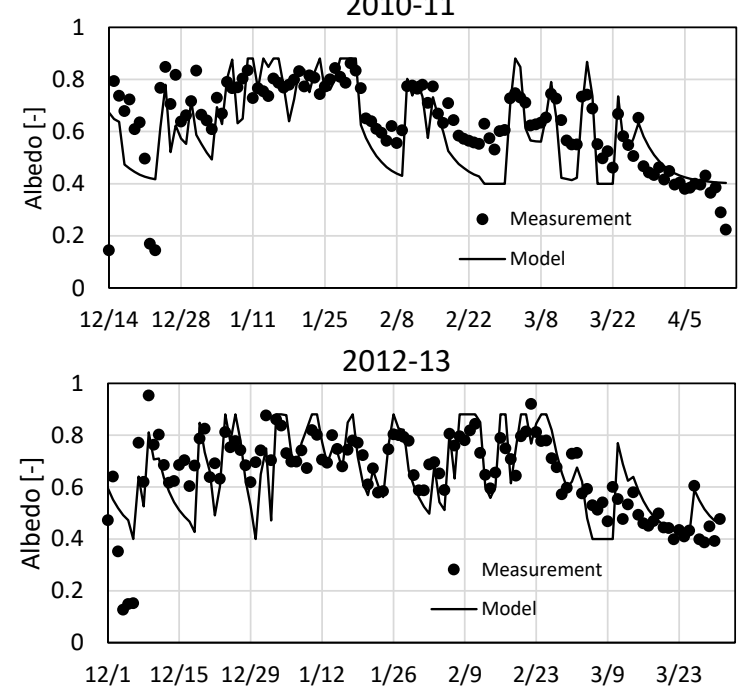

Fig.3 Comparison of the albedo obtained by observations and by the model

$C L W_{M A X}$ が $5 \%$ と $10 \%$ の条件において、 $T_{S R}$ を $0.2^{\circ} \mathrm{C}$ から $0.3^{\circ} \mathrm{C}$ 刻みで $2.0^{\circ} \mathrm{C}$ まで変化させた。例として、CL $W_{M A X}$ を $5 \%$ とし、 $T_{S R}$ を変化さ せた場合の代表 2 冬期の推定結果と観測結果の比較を Fig. 4 に示 す。全体的には、 $T_{S R}$ の值によらず一冬期における積雪重量の増減の 過程をよく捉えている。 $T_{S R}$ を高くすることで、積雪重量の増加ペー スが早くなり、重量のピークも大きくなる。また高い $T_{S R}$ は融雪の時 期を遅らせる傾向にある。 $0.5^{\circ} \mathrm{C}$ 以下は積雪重量を過小に推定してお り低すぎると判断できるが、それ以上の值では、冬期によって最適 值は異なるように見受けられる。そこで 8 冬期を対象に、2つの $C L W_{\text {MAX }}(5,10 \%)$ で、 $T_{S R}$ を同様に変化させた解析を行い、推定積 雪重量と観測積雪重量の誤差を比較した。誤差は NMSE (Normalized mean square error : 正規化平均二乗誤差) を次式に より求めた。

$$
\text { NMSE }=\frac{\overline{\left(P_{l}-O_{l}\right)^{2}}}{\bar{P}_{l} \cdot \bar{O}_{l}}
$$

$P$ は推定結果、Oは観測結果を意味する。またオーバーバーは全 データの平均を、添え字のiは各時刻のデータを示す。

8 冬期分の NMSE の平均值及び最大最小值を Fig. 5 に示す。 $T_{S R}=0.2^{\circ} \mathrm{C}$ で誤差の平均值と最大值が最も大きく、 $T_{S R}$ が高くなると ともに誤差は小さくなる。既往研究で $T_{S R}$ として用いられることの多 い $2.0^{\circ} \mathrm{C}$ は、 NMSE の平均值は比較的小さいものの冬期毎の偏差が やや大きくなる。CLW MAX $_{\text {は }} 5 \%$ と $10 \%$ の場合を比較すると NMSE の分布傾向に殆ど違いが見られない。1.1 $2.0^{\circ} \mathrm{C}$ 範囲の $T_{S R}$ 及び $C L W_{M A X}$ が NMSE に及ぼす影響は小さく、誤差も小さいと判断でき るが、以降の検討においては、NMSE の 8 冬期平均值が 0.126 と最 も小さかった、 $T_{S R}=1.4^{\circ} \mathrm{C} 、 C L W_{M A X}=5 \%$ を標準条件として採用する。

\section{3 精度検証}

上記の標準条件で、日別積雪重量の観測值と推定モデルの比較を 散布図として Fig. 6 に示す。図中の矢印は時間の進行を表す。冬期 によるばらつきはあるものの、概ね $45^{\circ}$ の線に沿って分布しており
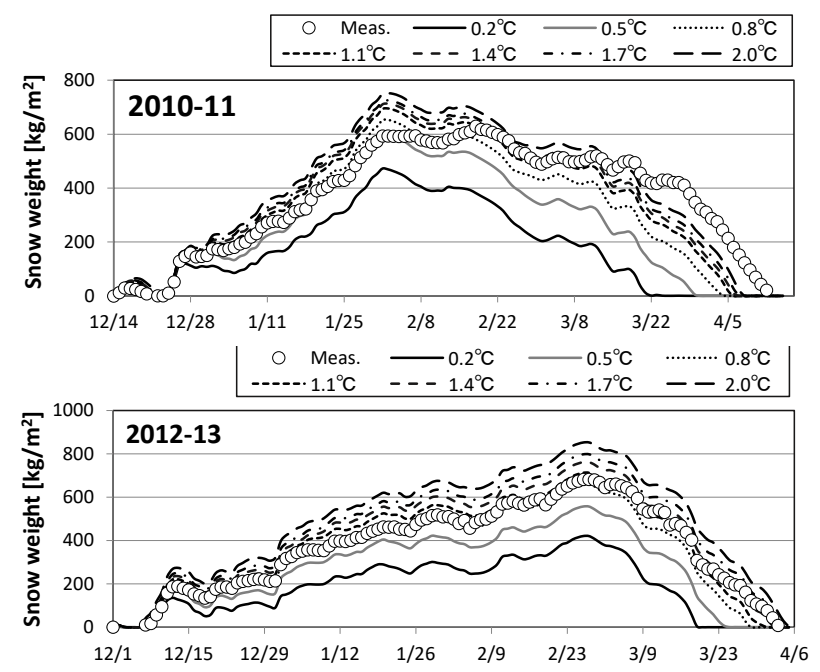

Fig. 4 Influence of $T_{S R}$ on estimated snow weights with $C L W_{M A X}=$ $5 \%$
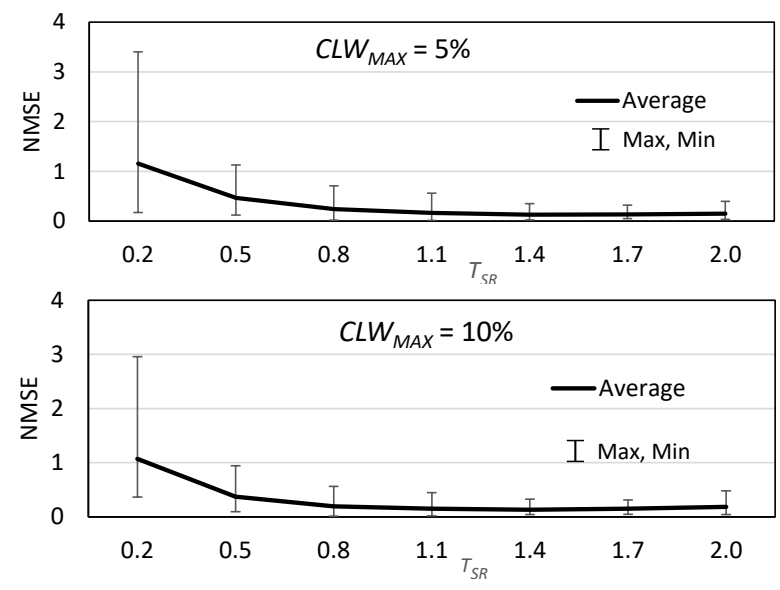

Fig. 5 Average and deviation of NMSE for eight winters with different $T_{S R}$ values

積雪重量の増減傾向を精度よく推定できている。積雪重量の小さい 時期において、プロットが $45^{\circ}$ の線の下側に分布する傾向にあり、 これはモデルが推定する融雪が観測結果よりも早く進んでいること を示している。結果は省略するが、 $T_{S R}$ をより高く設定すると融雪期 の積雪重量は観測とよく合うようになるものの、その分積雪重量の 上昇分が大きくなり、最大積雪重量を過大に評価するようになる。 各冬期の 7 日増分積雪重量についても同様に Fig. 7 に示す。プロッ 卜はほぼ $45^{\circ}$ の線上に分布しており、7 日増分積雪重量の方が地上 積雪重量よりも全体に精度が高い。

各冬期の最大積雪重量と最大 7 日増分積雪重量の推定值と観測値 の比較を相関図として Fig. 8 に示す。推定モデルがやや積雪重量を 大きめに予測する傾向があるものの、全体的に高い精度で予測でき ている。

\section{4. 熱収支モデルに基づく気象条件が積雪重量変化に及ぼす影響に} 関する考察

モデルによって推定された積雪重量と（3）式の熱収支式における 各エネルギー要素の経時変化を Fig. 9 に示す。2010-11 冬期では、 初期の積雪は、大きな融雪エネルギー $(M)$ によって、一度消雪し 

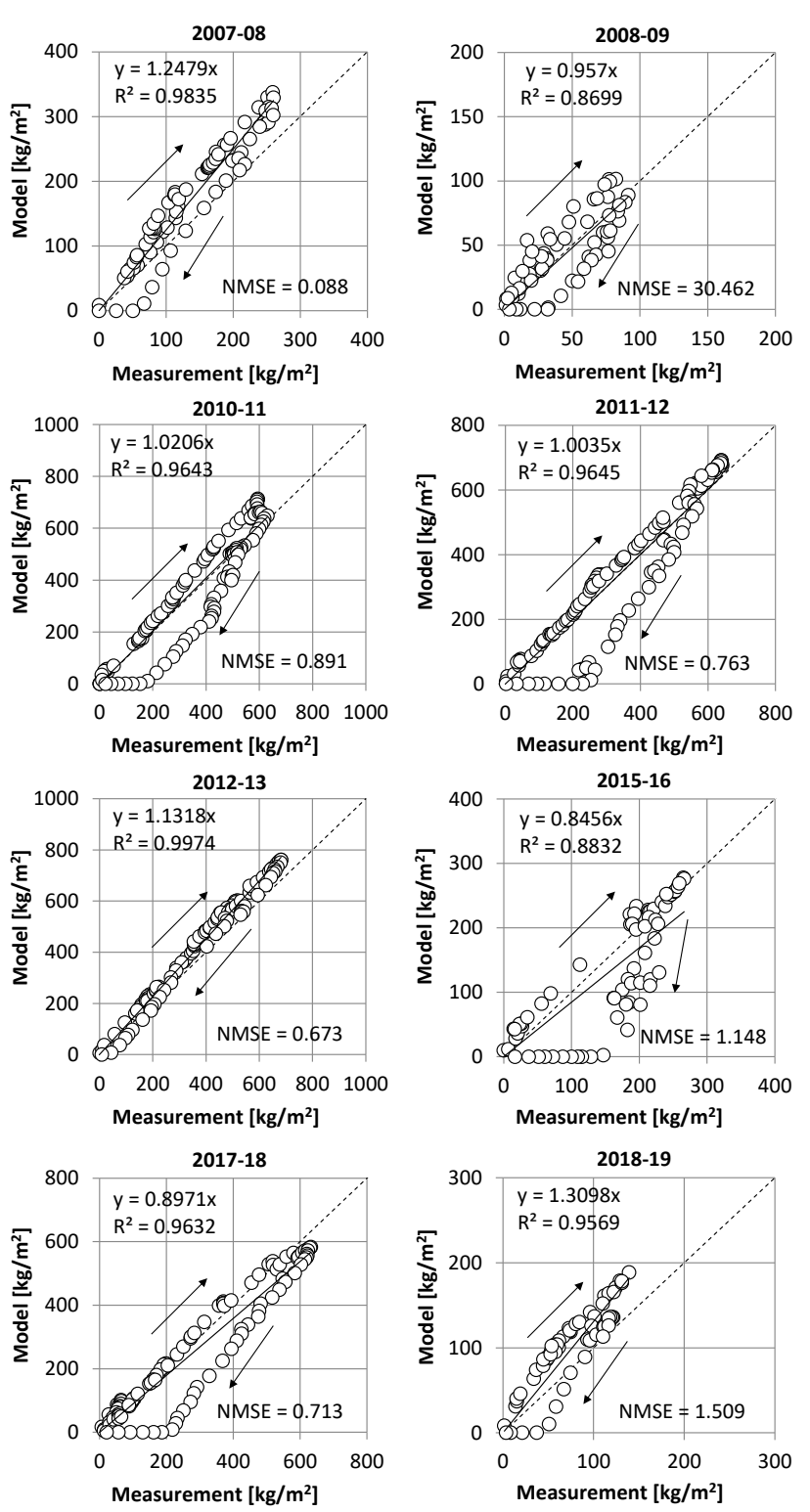

Fig. 6 Relationship between daily snow weights obtained using measurements and estimation model for eight winters
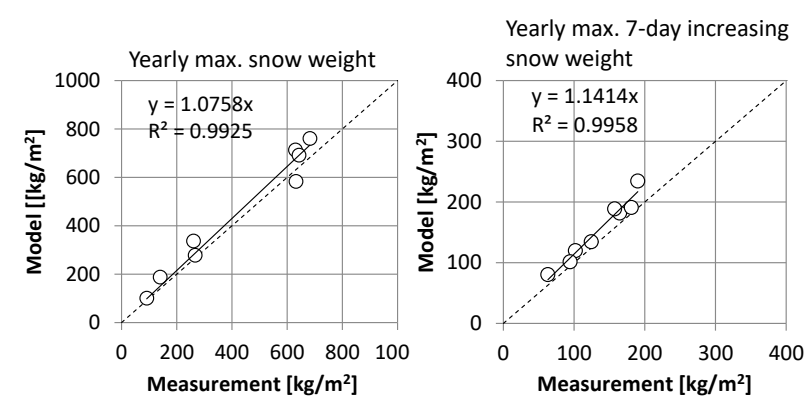

Fig. 8 Relationship of yearly maximums of daily and 7-day increasing snow weights obtained using measurements and estimation model for eight winters

ている。その後、積雪重量は比較的単調に増加し、その間の融雪エ ネルギー $(M)$ は小さい。 $2 / 2$ の積雪重量のピーク以降では、融雪エ
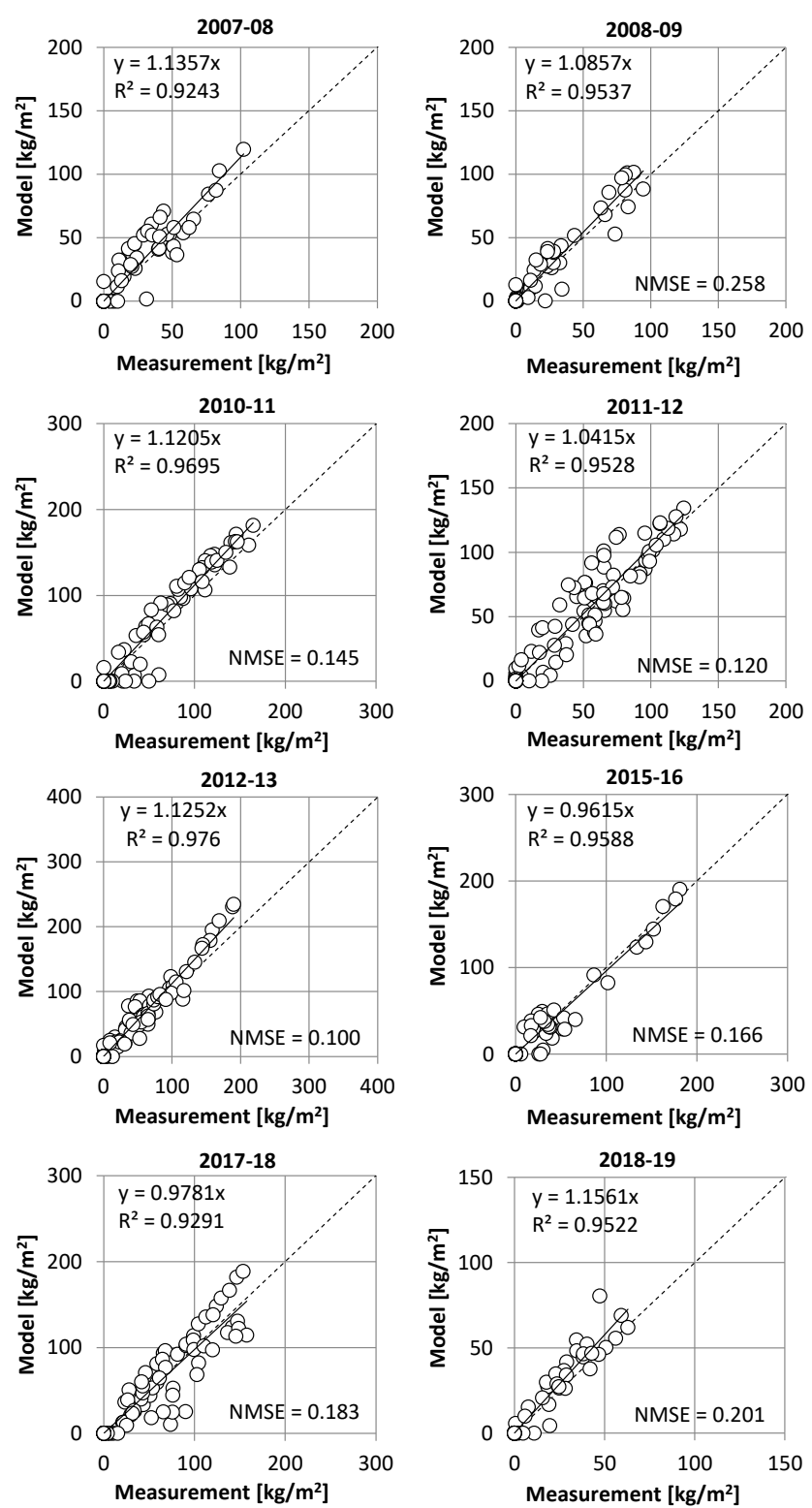

Fig. 7 Relationship of 7-day increasing snow weights obtained using measurements and estimation model for eight winters

ネルギーの上昇が何回か見られるようになり、その内訳は放射収支 $\left(R^{\downarrow}-L^{\uparrow}\right)$ による寄与が殆どであり、顕熱・潜熱輸送 $(H, l E)$ の寄 与は小さい。融雪エネルギーの上昇と積雪重量の減少のタイミング は対応しており、そのピークが大きいほど、積雪重量の減少も急と なる。2012-13 冬期においても、傾向は同様であるが、積雪重量の ピークが 2010-11 冬期より遅い時期（2/27）に現れているのは、そ の間の融雪エネルギー $(M)$ が小さいまま推移していることと対応 している。2 月末から融雪エネルギー（M）の上昇が何度も見られ るようになり、放射収支 $\left(R^{\downarrow}-L^{\uparrow}\right)$ によるものだけでなく、顕熱・ 潜熱輸送 $(H, l E)$ の寄与もある程度見られる。それに伴い、積雪重 量の減少の勾配は、2010-11 冬期に比べて急峻である。このように 積雪重量の増減の要因やメカニズムを定量的に理解できる点は熱収 支モデルに基づく本手法の大きなメリットである。 

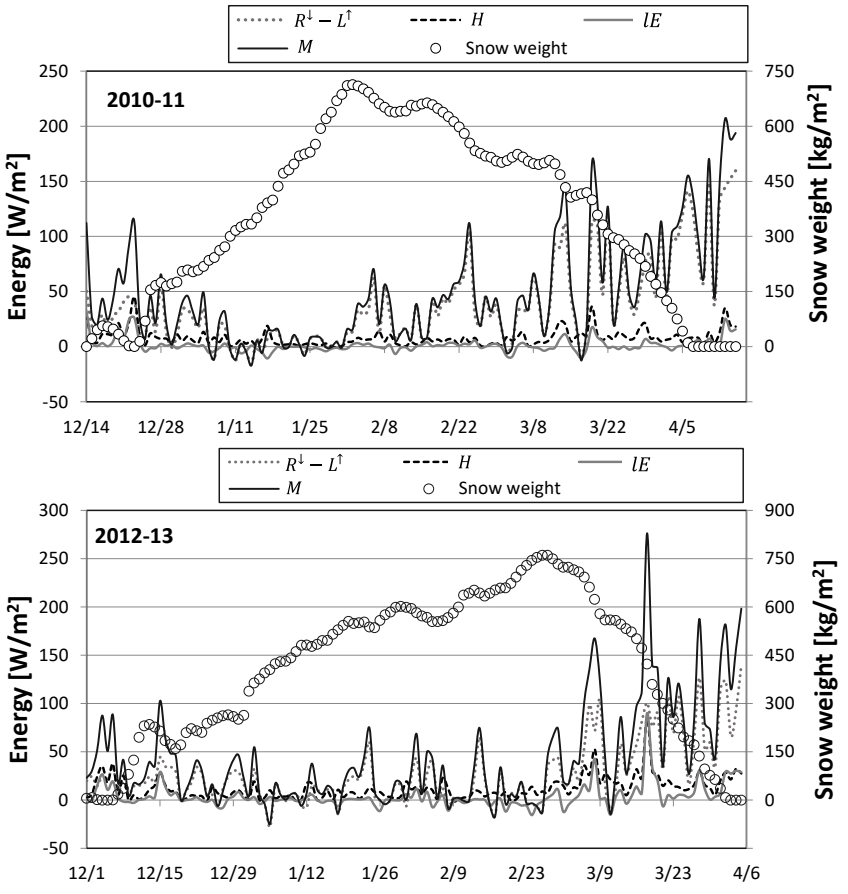

Fig. 9 Variations in heat balance components and ground snow weight

\section{AMeDAS 観測データへの拡張性の検討}

2.1 で述べたように、本推定法では、Table 1 に示した 7 つの気象 要素を必要とし、気象官署では全ての要素が計測されており入手可 能であるが、全国各地により多くの観測地点を有するアメダス観測 点においては入手できない気象要素があり、モデルのより幅広い地 点における適用という点で課題となる。その課題を克服する方法と して、建築環境・設備の分野で広く用いられている拡張アメダス気 象データ 21) の利用を検討寸る。拡張アメダス気象データは、アメダ スで観測された気象データの欠測を補充するとともに、アメダスで 観測されていない気象要素のデータを観測されている気象要素から 推定して整備された気象データである(以降 $\mathrm{EA}$ 気象データと呼ぶ)。 $\mathrm{EA}$ 気象データは、年別 EA 気象データとして 1981〜2010 年まで が整備・公開されているが (2020 年 8 月時点)、本研究で検討対象 としている全ての冬期のデータは整備されておらず、また本研究の 対象露場と最寄りのアメダス観測点（長岡）は $6 \mathrm{~km}$ 程度離れてお り、精度の検証には適さない。そこで、本研究の対象露場で計測さ れている気象要素のうち、アメダス観測点で計測されていない気象 要素はあえて使用せず、アメダス観測点で計測されている要素のみ を使用して、不足する要素を EA 気象データと同様の方法で推定し て、モデルの入力条件として精度を検証することとした。具体的に は、大気圧と水蒸気圧（相対湿度）は、文献 22 の方法に基づき、複 数の周辺の気象官署の観測值を距離の逆数の重みで荷重平均して推 定した。日射量は、文献 23,24 の方法に基づき、別途計算して求め た大気外水平面日射量と日照率、気温、降水量の観測值から推定し た。大気放射量は、文献 25 の方法に基づき、日照率、気温、降水量 を用いて推定した（以降これらをまとめて EA 推定と呼ぶ）。

実際に計測された気象要素を用いて算出された積雪重量と、アメ
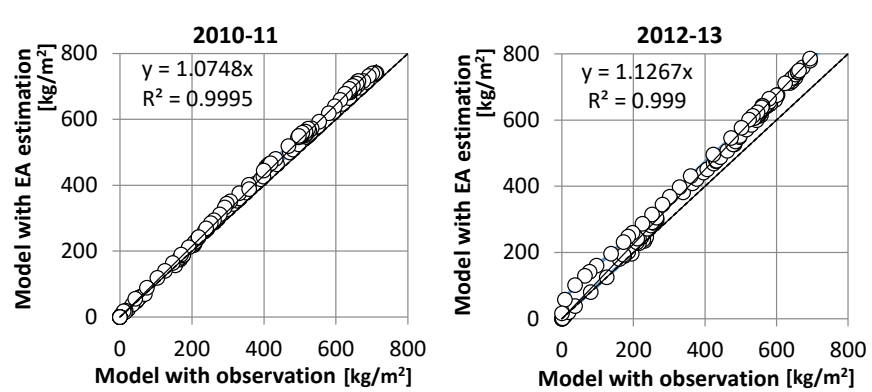

Fig. 10 Comparison of ground snow weights estimated using full observation data and using EA estimation

ダス観測要素以外を EA 推定して算出された積雪重量の比較を Fig. 10 に示す。EA 推定した気象データで計算された積雪重量が 1 割程 度大きめではあるものの、両者は高い相関を示す。すなわちアメダ ス観測点の気象要素を用いても、EA 推定を併用することにより、 本研究で提案する手法によって、気象官署のデータを使用する場合 と同等の精度で地上積雪重量を推定することが可能である。

\section{6. 結論}

本報では、気象観測データと熱収支モデルに基づく地上積雪重量 推定手法を構築し、その概要を示した。その手法を用いて、代表的 な積雪都市の一つである新潟県長岡市の詳細な気象観測データに基 づいて地上積雪重量を推定し、同条件下で計測された積雪重量の観 測值との比較を行い、以下の結論を得た。

1 ) 推定モデルで使用される雨雪判別気温 $T_{S R}$ は $1.1 \sim 2.0^{\circ} \mathrm{C}$ 範囲で は推定誤差の平均值に大きな差は生じない。また最大含水率は $5 \%$ と $10 \%$ では全体的な誤差に大きな違いは及ぼさない。本報で 検討した 8 冬期については、 $T_{S R}$ を $1.4^{\circ} \mathrm{C}$ 、最大含水率 $5 \%$ とした 場合が、NMSE が最も小さくなった。

2）上記の条件で推定した地上積雪重量、及び 7 日増分積雪重量の 日変化は、冬期によってばらつきはあるものの、特に年最大值に 関して、観測值に対して約 10\%以内の精度で推定できた。すな わち本手法が、既往の研究と比較しても十分な精度を有すること が確認できた。

3 ) モデルの解析結果から熱収支の内訳を分析すると、積雪重量の 減少に寄与寸る融雪エネルギーは、有効放射によるものが支配的 であることが確認できた。また今回の条件では、顕熱、潜熱輸送 による寄与は比較的小さかった。融雪エネルギーの増減と地上積 雪重量の増減は密接に関係しており、このように積雪重量の増減 の要因やメカニズムを理解できる点は熱収支に基づく本手法の 大きなメリットである。

4 ）必要な気象要素の観測が行われている地点が限られるという適 用性の課題に対して、拡張アメダス気象データと同様の手法に よってアメダス観測点の気象要素を用いて不足する気象要素を 推定する方法の有効性を検討し、アメダス観測データしか得られ ない地点においても十分な精度で本モデルの適用が可能である ことを示した。

なお本論文では、長岡市における観測データに基づき推定モデル 
の精度を検証した結果を示した。言うまでもなく、気象条件や雪質 の異なる他の地点への本モデルの適用性の有無の確認は大きな課題 である。本論文で示した通り、本手法で使用するモデルパラメータ の選択に対する結果の感度は比較的小さく、地域依存性はあまり大 きくないと予想されるが、具体的な検証結果は、続報にて報告する 予定である。また本論文で提案した地上積雪重量推定モデルを屋根 荷重の推定に拡張する検討も、観測結果 26) との比較に基づき、進め ていく予定である。

\section{謝辞}

本研究は科学研究費 $(16 \mathrm{H} 04467,20 \mathrm{H} 02315)$ の助成を受けて行わ れた。本研究の実施にあたり、新潟工科大学建築学科及び工学科 4 年生（当時）廣川昂大氏、青木空氏、丸山司氏のご協力を得た。防 災科学技術研究所・雪水防災研究センターの観測データの使用に際 しては、同センター山口悟研究員に便宜を図って頂いた。また新潟 工科大学 風・流体工学研究センターの伊部文子さんにはデータ整 理と版下原稿作成にご協力頂いた。記して謝意を表す。

\section{注}

注 1) 別途精度の検証は必要であるが、本モデルをより長い時間間隔（例えば 3 時間）の気象データに対して適用することも原理的には可能である。 注 2) 空気密度は次式により求めた。

$$
\rho=\mathrm{P} /\{R(t+273.15)\}
$$$$
P \text { : 大気圧 }[\mathrm{hPa}], R=2.87, t: \text { 気温 }\left[{ }^{\circ} \mathrm{C}\right]
$$

注 3）文献 10 によれば、雪面上の顕熱輸送および潜熱輸送のバルク係数は、 既往の研究例のほとんどが $C_{H}, C_{E}$ とも $1.5 \sim 3 \times 10^{-3}$ に入っているとされ、近 藤・山崎 ${ }^{15)}$ の用いた 0.002 を変更する根拠は希薄と考え、 $C_{H}, C_{E}$ ともその ままの值を用いた。

注 4）気温 $T$ における飽和比湿 $[\mathrm{kg} / \mathrm{kg}]$ は次式で求めた。

$\rho_{\text {sat }}(T)=0.622 \mathrm{e}_{\text {sat }}(T) /\left(p_{s}-0.378 \mathrm{e}_{\text {sat }}(T)\right)$

気温 $T$ における飽和水蒸気圧 $[\mathrm{hPa}]$ は次式で求めた。 $\mathrm{e}_{\text {sat }}(T)=6.108 \times 10^{(7.5 T / 237.5+T)}$

注 5) 飽和比湿の温度 $T$ に対する変化率は次式で求めた。

$$
\Delta \equiv \frac{d q_{\text {sat }}}{d T}=\frac{d e_{\text {sat }}}{d T} \times \frac{0.622 p_{s}}{\left(p_{s}-0.378 e_{s a t}(T)\right)^{2}}=\frac{4098.03}{(237.3+T)^{2}} \times e_{\text {sat }}(T)
$$

注 6) 不凍液で満たされ、パイプで連結されている 4 枚のメタルウェハーを 地表に設置し、その上に積もった積雪による内部圧力の変化を測定するこ とにより、積雪重量を求める方式である。

注 7）アルベドの観測值は、春先の融雪期に 0.4 を下回っている場合もあり、 $a_{\text {min }}=0.4$ という設定によってこの時期の融雪量を過小に評価する可能性 がある。しかし、この值をさらに低く設定することで、本研究の主たる目 的である積雪重量の大きい期間のアルベドを過小評価することの影響の方 が大きいと考え、文献 17 での $a_{\text {min }}$ の值である 0.4 をそのまま用いた。

\section{参考文献}

1) Otsuki, M. et al.: Study on Estimation Method for Surcharge Snow Load due to Rainfall, Journal of Structural and Construction Engineering (Transactions of AIJ), Vol.82, No.739, pp.1329-1338, 2017.9 (in Japanese)

大槻政哉ほか 9 名：降雨を考慮した積雪荷重の推定方法に関する研究，日 本建築学会構造系論文集, 第 82 巻, 第 739 号, 1329-1338, 2017.9

2) Chiba, T. and Takahashi, T.: Evaluation of Snow Load based on Precipitation Data, 2014nen 2gatsu no ooyuki to sekisetsugo no kouu wo fumaeta kenchikubutsu no taisetsusekkei ni kansuru symposium, AIJ, pp.19-24, 2017.11 (in Japanese)

千葉隆弘, 高橋徹 : 降水量をベースにした雪荷重評価について, 2014 年 2 月の大雪と積雪後の降雨を踏まえた建築物の対雪設計に関するシンポジウ 厶, 日本建築学会, pp.19-24, 2017.11

3) O'Rourke, M.: Snow Loads - Guide to the Snow Load Provisions of ASCE
7-16, American Society of Civil Engineers, 2017.8

4) Architectural Institute of Japan (AIJ): Snow load, Recommendations for Loads on Buildings (2015), pp.214-235, 2015 (in Japanese)

日本建築学会 : 雪荷重, 建築物荷重指針・同解説 (2015), pp. 214-235, 2015

5) Takahashi, T., Kawamura, T. and Kuramoto, K.: Estimation of Ground Snow Load using Snow Layer Model, Journal of Structural and Construction Engineering (Transactions of AIJ), No.545, pp.35-41, 2001.7

高橋徹, 川村大樹, 倉本幸治 : 積雪層モデルによる地上積雪重量の推定, 日 本建築学会構造系論文集, 第 545 号, pp.35-41, 2001.7.

6) Sakurai, S. and Joh, O.: Fundamental Study on the Estimation of Ground Snow Weights and Equivalent Snow Densities Based on the Meteorological Data, Journal of Snow Engineering of Japan, Vol.17, No.3, pp.10-21, 2001.7 (in Japanese)

桜井修次, 城 攻 : 気温・降水量記録に基づく地上積雪重量の推定法および 等価単位積雪重量の評価に関する基礎的研究, 日本雪工学会誌, 第 17 巻,

第 3 号, pp.194-205, 2001.7

7) Sakurai, S. and Joh, O.: Estimation of Ground Snow Weights Based on the Data of Daily Precipitations and Daily Mean Air Temperatures, Summaries of Technical Papers of Annual Meeting, Architectural Institute of Japan. B. Structures I, pp.75-76, 1994.7 (in Japanese) 桜井修次, 城 攻, 気温、降水量資料に基づく地上積雪量の推定に関する考 察, 日本建築学会大会学術講演梗概集 B, 構造 I, pp.75-76, 1994.7

8) Kamimura, S. and Umemura, T.: A Proposal for Effective Design of Snow-melting System, Journal of Snow Engineering of Japan, Vol.12, No.3, pp.212-217, 1996.7 (in Japanese)

上村靖司, 梅村晃由: 屋根融雪装置の能力設計に関する提案, 日本雪工学 会誌，第 12 巻，第 3 号, pp.212-217, 1996,7

9) Kawashima, K., Iikura, S., Sugiyama, T., Endo, T. and Fujii, T.: Development of a Simple Method for Estimating Daily Amount of Snowmelt with the Object of Application to Railway Disaster Prevention, Journal of the Japanese Society of Snow and Ice (Seppyo), Vol.64, No.6, pp.605-615, 2002.11 (in Japanese)

河島克久，飯倉茂弘，杉山友康，遠藤徹，藤井俊茂 : 鉄道防災に適用可能 な日融雪量の簡易推定方法, 雪水, 第 64 巻, 第 6 号, pp.605-615, 2002.11

10) Kondo, J.: Mizukankyou no kisyougaku - Chihyoumen no mizusyuushinetsusyuushi-, Asakura Publishing Co., Ltd., 1994 (in Japanese) 近藤純正 編著 : 水環境の気象学 一地表面の水収支・熱収支一, 朝倉書店, 1994

11) Hirashima, H., Yamaguchi, S., Kosugi, K., Nemoto, M., Aoki, T. and Matoba. S.: Validation of the SNOWPACK Model using Snow Pit Observation Data, Journal of the Japanese Society of Snow and Ice (Seppyo), Vol.77, No.1, pp.5-16, 2015.1 (in Japanese)

平島寛行，山口悟，小杉健二，根本征樹，青木輝夫，的場澄人：断面観測 結果を用いた積雪変質モデルの検証, 雪水, 第 77 巻, 第 1 号, pp.5-16, 2015.1

12) Fujimoto, A., Terasaki, H. and Fukuhara, T.: A Roof Snow Load Model by a Heat, Ice, Water and Air Balance Method, Vol.70, No.4, pp.I_427I_432, 2014 (in Japanese)

藤本明宏, 寺崎宽章, 福原輝幸 : 熱・水・水分・空気収支法による屋根雪 荷重モデル, 土木学会論文集 B 1 (水工学), 第 70 巻, 第 4 号, pp.I_427I_432, 2014 .

13) Yamaguchi, S., Hirashima, H., Ishizaka, M., Sato, A. and Lehning, M. A Study of Snow Cover Structures in 2005/2006 Winter Season Using a Numerical Snow Cover Model, Cold Region Technology Conference 2006, pp.44-48, 2006.11.29-12.1 (in Japanese)

山口悟, 平島寛行, 石坂雅昭, 佐藤篤司, Lehning, M. : 積雪変質モデルを 用いた平成 18 年豪雪における積雪特性の研究, 第 22 回寒地技術シンポジ ウム, pp.44-48, 2006.11.29-12.1.

14) Yokoyama, K., Ohno, H., Kominami, Y., Inoue, S. and Kawakata, T.: Performance of Japanese Precipitation Gauges in Winter, Journal of the Japanese Society of Snow and Ice (Seppyo), Vol.65, No.3, pp.303-316, 2003.5 (in Japanese)

横山宏太郎, 大野宏之, 小南美靖弘, 井上聡, 川方俊和, 冬期における降 水量計の捕捉特性, 雪水, 第 65 巻, 第 3 号, pp.303-316, 2003.5

15) Kondo, J. and Yamazaki, T.: Estimates of Snowmelt by a Heat Balance 
Method, Journal of the Japanese Society of Snow and Ice (Seppyo), Vol.49, No.4, pp.181-191, 1987.12 (in Japanese)

近藤純正, 山㠃剛: 熱収支法による融雪量の予測, 雪水, 第 49 巻, 第 4 号, pp.181-191, 1987.12

16) Kawashima, K., Endo, T. and Takeuchi, Y.: A portable Calorimeter for Measuring Liquid-water Content of Wet Snow, Annals of Glaciology, Vol.26, pp.103-106, 1998

17) Yamazaki, T., Taguchi, B. and Kondo, J.: Estimation of the Heat Balance in a Small Snowcovered Forested Catchment Basin, Tenki, Vol.41, No.2, pp.71-77, 1994.2 (in Japanese)

山㠃剛, 田口文明, 近藤純正 : 積雪のある森林小流域における熱収支の評 価，天気，第 41 巻，第 2 号，pp.71-77, 1994.2

18) Iyobe, T., Kawashima, K. and Togari, A.: Ondantasetsuchiiki ni tekiyoukanou na albedo model no kentou, Annual Report of Research Institute for Natural Hazards and Disaster Recovery, Niigata University, pp.77-78, 2013.9 (in Japanese)

伊豫部勉, 河島克久, 外狩麻子 : 温暖多雪地域に適用可能なアルベドモデ ルの検討, 新潟大学災害・復興科学研究所年報, pp.77-78, 2013.9

19) Yamaguchi, S. et al.: Measurement of specific surface area of fresh solid precipitation particles in heavy snowfall regions of Japan, The Cryosphere, vol. 13, pp. 2713-2732, 2019.10

20) Yamaguchi, S., Hirashima, H., and Ishii, Y.: Year-to-year changes in preferential flow development in a seasonal snowpack and their dependence on snowpack conditions. Cold Regions Science and Technology, vol. 149, pp.95-105, 2018.5

21) Meteorological Data System Co., Ltd. https://www.metds.co.jp/product/ea/ (accessed 2020.9.8)

株式会社気象データシステム https://www.metds.co.jp/product/ea/ (2020.9.8 閲覽)

22) Nimiya, H., Akasaka, H. and Matsuo, Y.: A Method for Appending Hourly Vapor Pressure to AMeDAS Data, Transactions of the Society of Heating, Air-conditioning and Sanitary Engineers of Japan, Vol.21, No.62, pp.39-51, 1996.7 (in Japanese)

二宮秀與, 赤坂裕, 松尾陽: AMeDAS データへの時刻別水蒸気圧の追加方 法, 空気調和 ・ 衛生工学会論文集, 第 21 巻, 第 62 号, pp.39-51, 1996.7

23) Nimiya, H., Akasaka, H., Sugai, T. and Kuroki, S.: A Method to Estimate the Hourly Solar Radiation using AMeDAS Data, Transactions of the Society of Heating, Air-conditioning and Sanitary Engineers of Japan, Vol.14, No.39, pp.13-23, 1989.2 (in Japanese)

二宮秀與, 赤坂裕, 須貝高, 黒木荘一郎 : AMeDAS のデータを用いた時刻 別日射量の推定法, 空気調和・衛生工学会論文集, 第 14 巻, 第 39 号, pp.13$23,1989.2$

24) Nimiya, H., Akasaka, H., Matsuo, Y. and Soga, K.: A Method to Estimate the Hourly Solar Radiation Using AMeDAS Data : Part 2Application to the Improved Sunshine Recorder of AMeDAS, Transactions of the Society of Heating, Air-conditioning and Sanitary Engineers of Japan, Vol.22, No.65, pp.53-65, 1997.4 (in Japanese) 二宮秀與, 赤坂裕, 松尾陽, 曽我和弘：AMeDAS のデータを用いた時刻別 日射量の推定法 第 2 報一回転式日照計および改良型太陽電池式日照計一 の適用, 空気調和・衛生工学会論文集, 第 22 巻, 第 65 号, pp.53-65, 1997.4 25) Nimiya, H., Akasaka, H. and Matsuo, Y.: A Method to Estimate the Hourly Downward Atmospheric Radiation using AMeDAS Data, Transactions of the Society of Heating, Air-conditioning and Sanitary Engineers of Japan, Vol.21, No.60, pp.133-144, 1996.2 (in Japanese) 二宮秀與, 赤坂裕, 松尾陽 : AMeDAS のデータを用いた時刻別大気放射量 の推定法, 空気調和・衛生工学会論文集, 第 21 巻, 第 60 号, pp.133-144, 1996.2

26) Tominaga, Y., Igarashi, K., Wakui, M., Motoyoshi, H. and Takada, S.: Development of a semi-full-scale building model to obtain validation data for evaluation model of roof snow load, AIJ Journal of Technology and Design, No. 65, pp. 114-118, 2021. 2 (in Japanese)

富永禎秀, 五十嵐賢次, 涌井将貴, 本吉弘岐, 高田清太郎 : 屋根雪荷重推 定モデルの検証用データ取得を目的とした準実大建物モデルの開発，日本 建築学会技術報告集, No. 65, pp. 114-118, 2021. 2 


\section{Yoshihide TOMINAGA ${ }^{* 1}$ and Hiroki MOTOYOSHI ${ }^{* 2}$}

${ }^{1}$ Prof., Faculty of Engineering, Niigata Institute of Technology, Ph.D.

${ }^{2}$ Researcher, Snow and Ice Research Division, National Research Institute for Earth Science and Disaster Resilience, Ph.D.

Accurate estimation of roof snow load is important for safely ensuring the structural performance of buildings in snowy regions. Ground snow weight is a basic design factor used to calculate the roof snow load. In a previous model, the ground snow weight was estimated based on daily precipitation and average temperature. However, this model has a limitation in terms of its universality because it is necessary to optimize the coefficients used in the model by comparing the calculated result with observation data in advance.

This study aims to develop a versatile and universally applicable method to estimate ground snow weight based on meteorological observation data and a heat balance model. The proposed model is based on the concept that the snow weight can be estimated by subtracting the snowmelt runoff from the total precipitation. The model proposed by Kondo and Yamazaki (1987) was used to calculate the amount of snowmelt. The ground snow weights were estimated through the proposed model using detailed meteorological observation data for Nagaoka, which is representative of a snowy city in Japan.

According to the estimation results, the threshold temperature of rain/snow, $T_{S R}$, used in the model did not significantly affect the error in the range of 1.1 to $2.0^{\circ} \mathrm{C}$. Additionally, the maximum water content values, $C W V_{M A X}$, of $5 \%$ and $10 \%$ did not show large differences in the estimation error. For the eight winter examples examined in this study, the average normalized mean square error (NMSE) was the smallest when $\mathrm{T}_{\mathrm{SR}}$ was $1.4^{\circ} \mathrm{C}$ and the maximum water content was $5 \%$. Although the accuracy varies with the winter, the variations in the daily ground snow weight and 7-day increasing snow weight were correctly estimated with an error of approximately $20 \%$. The maximum values of each winter were predicted within an error of approximately $10 \%$.

By analyzing the heat balance components obtained by the model, it was confirmed that the snowmelt energy due to radiation mainly contributed to the decreasing snow weight. Under the conditions of the present study, the contributions of sensible and latent heat transport were small. An estimation method based on the heat balance model, as developed in this study, can be helpful for understanding the factors contributing to the variation in the snow weight. This is a great advantage of such a model.

The present method has a limitation in its applicability; that is, all meteorological factors required in the model are only available at very limited sites such as meteorological offices. To overcome this limitation, a method was examined through which unavailable meteorological factors were estimated by meteorological factors measured at AMeDAS observation points; this method was similar to extending AMeDAS meteorological data. As a result, it was shown that the present method can be applied with sufficient accuracy even at sites where only AMeDAS meteorological data are available. 